\title{
Factors Affecting Investment Decision in the Saudi Stock Market
}

\author{
Meshari Alhussain ${ }^{1}$ \\ ${ }^{1}$ College of Business Administration, Umm Al-Qura University, Makkah, Saudi Arabia \\ Correspondence: Meshari Alhussain, College of Business Administration, Umm Al-Qura University, Makkah, Saudi \\ Arabia.
}

Received: May 2, 2020

Accepted: May 18, 2020

Online Published: May 24, 2020

doi:10.5430/ijba.v11n3p107

URL: https://doi.org/10.5430/ijba.v11n3p107

\begin{abstract}
This research aims to explore the factors influencing the decision of investment in the Saudi Arabian stock market which are the following factors: the analysis and financial ratios, the history and reputation of the company, dividends, date of the company's founding, company size, recommendations and opinions of analysts, the nature of the company's activity) and its impact on investment decision. A questionnaire has been used as a research tool, the study group consisted of all individuals investing in the Saudi stock market in 2018, and the sample was selected in an available way which is one type of non-random sample, with a total of 128 valid questionnaires for analysis out of 130 questionnaires. The research on its theoretical side touched on the efficiency and importance of the market, the types of financial markets, the formation and evolution of the Saudi stock market, the period of collapse of the Saudi stock market, the post-collapse Saudi stock market. While the tests of reliability and stability (Cronbach's alpha coefficient), frequencies, percentages, arithmetic averages and standard deviation, (T- test) for differences between two independent samples (independent sample T-test), one-way analysis of variance (one-way ANOVA) were used in the practical aspect of the research. The research has found an effect of the following factors: analysis and financial ratios, the history and reputation of the company, dividends, date of the company's founding, company size, recommendations and opinions of analysts, the nature of the company's activity) on investment decision.

The most influential factor on investment decision is the analysis and financial ratios, followed by the reputation and history of the company, dividends and its impact on investment decision ranked third, while date of the company's founding ranked fourth in terms of influencing investment decision, while the nature of the company's activity ranked fifth in terms of impact, followed by company size in the sixth rank, and finally recommendations and opinions of analysts ranked seventh and last in terms of influencing the decision of investment in the Saudi stock market.
\end{abstract}

Keywords: Saudi stock market, investing in stock market, influences in investment decision

\section{Introduction of the Study and Its Methodological Framework}

\subsection{Introduction}

Financial markets are an important centre and a point of contact between investors and firms through the provision of financial liquidity and its transfer to investments that contribute to the economic development of states. Investment in equities is considered to be one of the types of investment in securities (Al-Habashneh et al., 2015). The total return of investment in securities is usually one of two ways (Capital Market Authority, 2018): (Capital gains achieved when prices rise and securities are sold at more than the cost of purchasing, income from distributions paid by stock companies).Securities are convertible and circulating shares of companies, debt instruments such as negotiable bonds issued by governments or companies, i.e., instruments representing the rights of contribution dividends, and any rights to the distribution of assets or one of them (Note 1). Stock markets are an essential component of the structure of the financial sector in the state's economy; the financial sector consists of many financial instruments used by both individuals and companies to accumulate their savings. These instruments contribute to the creation of multiple projects, which continue to expand and spread if the most important elements of production are available, which are money (Al-Rajhi \& Al-Manasy, 2017). In order to have a financial market with a high efficiency in its performance, it must be fair and secure, and this is achieved by giving equal opportunities to all those who sell and buy in the market, as well as by developing legislation to protect against risks that may arise among market operators such as the risks of fraud and bankruptcy (Al-Hossan, 2002). One of the most important functions of the stock market at the 
level of the national economy (national capital settlement, mobilization and channelling of savings towards investment in economic projects, attraction of foreign capital, paving the way for the authorities to blend fiscal and monetary policies. A market is a key indicator of the reality of the economic situation) (Yacoub, 2006). Fiscal policy is: government expenses or expenditures and government revenues (taxes and fees), while monetary policy is: the money supply where monetary policy is based on the adjustment of the money supply to influence interest rates (Capital Market Authority, 2018).

\subsection{Research Problem}

Stock prices in the financial market are characterized by wide fluctuations as a result of many factors associated with the nature of the environment in which a financial market is experiencing. Most of the decisions taken by the contributing companies are also based on factors that affect prices of companies' shares (Al-Rajhi \& Al-Manasy, 2017).The research problem summarizes in the following question: what are the factors influencing an investor's decision in the Saudi stock market? And what is the level of their significance for an investor? Under this question, there are several questions:

1. Does an investor's decision in the money market depend on analysis and financial ratios when trading securities?

2. Does an investor's decision in the money market depend on the reputation and history of the company when trading securities?

3. Does an investor's decision in the money market depend on dividends when trading securities?

4. Does an investor's decision in the money market depend on the company's founding date when trading securities?

5. Does an investor's decision in the money market depend on the company's size when trading securities?

6. Does an investor's decision in the money market depend on the recommendations and opinions of financial analysts when trading securities?

7. Does an investor's decision in the money market depend on the nature of the company's activity when trading securities?

\subsection{Research Objective}

The aim of the study was to try to identify the factors influencing investors' decisions in the Saudi Arabian capital market, as follows:

1. Are investors interested in analysis and financial ratios before making a trading decision in the company?

2. Are investors interested in the company's history and reputation before making a trading decision in the company?

3. Are investors interested in dividends before making a trading decision in the company?

4. Are investors interested in the company's founding date before making a trading decision in the company??

5. Are investors interested in the company's size before making a trading decision in the company?

6. Are investors interested in the recommendations and opinions of financial analysts before making a trading decision in the company?

7. Are investors interested in the nature of the company's activity before making a trading decision in the company?

\subsection{Research Significance}

The success of investors ' investment decision requires them to understand their psychological and financial circumstances, their willingness to face potential risks, understanding of the behavioural factors of investors, individual tendencies and ways of thinking which play a key role in influencing stock prices (Al-Naggar, 2017). As an investor seeks mainly to gain profit in the stock market through the collection of dividends distributed to shareholders as well as capital profits achieved through the difference between the stock price at the time of sale and the stock price upon purchase (Shahat et al., 2012).

Financial markets are also an interest for the authorities and governments in all countries of the world, as they play a key role in boosting economic development by accumulating the savings of individuals and institutions and transforming them into investment channels and the Saudi capital market is one of the largest stock markets in the Arabic region (Al-Hossan, 2002). The practical reality of the Saudi stock market shows that there is an urgent need to recognize the most important variables affecting trading activity, in addition to that dealing with the market without a deep understanding of behavioural biases of market investors leads to a market shift away from efficiency (Mansi, 2009). 


\subsection{Research Hypotheses}

1. There is a relationship between the analysis, financial ratios and investment decision- making.

2. There is a relationship between the reputation, history of the company and investment decision- making.

3. There is a relationship between dividends and the investment decision- making.

4. There is a relationship between the company's founding date and investment decision- making.

5. There is a relationship between the company's size and investment decision- making.

6. There is a relationship between the recommendations and opinions of analysts and investment decision- making.

7. There is a relationship between the nature of the company's activity and investment decision- making.

\subsection{Previous Studies}

(Hatef \& Al-Zubaidi, 2000) study aimed to explore the level of understanding and using accounting information included in the financial reports during making decisions of individual investors in sale and purchase of companies' shares registered in the investment market in Baghdad. To achieve the study objective, a questionnaire was prepared and distributed to 46 individual investors. The study' results showed that the investors understand accounting information that was sufficient to them and know the importance of accounting information. In addition, the results showed that other non-financial information affects their decisions significantly, especially the advices of mediators, market publications, magazines, journals and advertisements, and individual investors use accounting information slightly, and the reports of the auditors and boards of management affect the decisions of exchanging with companies' shares.

(Al-Hossan, 2002) study aimed to provide an analytical and comprehensive view for the trends and patterns of the investment behavior for the Saudi Investor in the Saudi Stock Market. The questionnaire was used as a tool for the study. The study was applied to a random sample that included (2000) investors who practice their investment activity in Al-Qassim Region in the Kingdom of Saudi Arabia. The study found that the majority of the investors were dealers and adventurers; the ages of all investors were over twenty years; investment in the stock market is less risky in comparison to investments in other sectors. In addition, investors rely on their experience in making investment decisions and there is a positive relationship between educational level and investment in the Saudi Stock Market.

(Basheikh, 2006) study aimed to determine the most important accounting information that affect the decisions of small investors in the Saudi Stock Market, as well as identify the most important variables that affect the prices of Saudi Shares. The study relied on the data of the companies registered in the Stock Market during the period from 2001 to 2005. Stepwise Regression Model was used as a tool for testing the study hypotheses. The study concluded that the proposed model include some indicators that may help small investors in rationalizing their investment decisions including; earnings per share, profits multiplier and price multiplier, distributed profit per share, return of distributed profit, book value and rate of return on owner's equity.

(Al-Buhaisi \& Najm, 2009) study focused on identifying the level of awareness for investor with the importance of accounting information and the adequacy of information in the financial reports and the level of depending on it to rationalize investment decisions. In order to achieve the study objectives, a questionnaire was designed and distributed to 185 investors in the Palestinian Stock Market. The study found that investors in the financial market know the importance of accounting information in rationalizing investment decision. As well as, accounting information, included in the financial reports of companies, is not sufficient, but it is often used to make investment decisions. The study showed that there are several obstacles that limit the use of accounting information in rationalizing the investment decision, including lack of confidence in the financial reports of companies, lack of experience for investors in financial matters and financial analysis, insufficient of information as quickly as required, as well as the difficulty of comparison between the financial lists of various companies.

(Mansi, 2009) study aimed to describe the Saudi investors and discuss the most important cognitive and emotional biases that affect the investor's decision making in shares, as well as, divide individual Saudi investors into various sectors in terms of cognitive and emotional biases. The study population was limited to securities individual investors without institutional investors in specific cities; including Riyadh, Jeddah, Al-Qassim, Makkah and Hail. Data were collected in 2007. The study followed the investigation method through an interview with the investors. Thirty two (32) graduate students were recruited to collect data and 459 valid lists were collected for analysis. The study concluded that investors can't be treated as one identical society. As well as, the Saudi investors can be divided into four sectors according to their cognitive and emotional biases as following: the first sector includes unstable 
persons, where the market fluctuations lead to their turbulences among markets; the second sector includes stable persons who represent the majority, and they won't exit from the market or turn to other investment when the market decreases significantly; the third sector is the flock group that distinguished by satisfaction with their decisions if they approved with the decisions of the majorities in the market; and the fourth sector is the risky persons who represent the minority and distinguished by high level of risk to obtain the highest possible return.

(Shahat et al., 2012) study aimed to examine the nature of the relationship between behavioral factors and the decisions of investors in the Egyptian Stock Exchange, as well as determine the nature of direct and indirect effects of the demographic characteristics of investor (age, gender, investment experience and educational level) and his patterns of investment decision. The study focused on all investors in the Egyptian Stock Exchange whose number was one million and nine hundred thousand investors. The sample, which represented the investors' categories, included 340 valid questionnaires for analysis. On the field side, the study used the questionnaire as a tool to test the hypotheses of the study. The study found that there is an effect of demographic characteristics and investors' categories on the investment decision. As well as, there is an impact between demographic characteristics, investor's emotion and investment decision; there is an impact between demographic characteristics, excessive confidence and investment decision; there is an impact between demographic characteristics, exaggeration and reduction in reaction and investment decision. Finally, there is an impact between demographic characteristics, flock behavior and investment decision.

(Al-Nemrouti \& Al-Owaisi, 2012) study aimed to identify the trends of individual investors in the Stock Market in Palestine through examining factors affecting the behaviors and trends of investors. As the study dealt with several factors, including investment awareness, stability of investment environment, performance of companies registered in the stock market and the level of market performance. The study used the questionnaire as a tool for the study. The study found that there is an interest by the investors in following up the news of business and money. Cadres of mediated companies in the stock market are not qualified to help the investors to make their investment decisions. As well as, the study concluded that rumors have an impact on investment decisions. The earnings per share in profits distributions influence the investment decision for the investors. Large rate of the investors take into account the total earnings per share in comparison with its price of purchase during making the investment decision, the religious influence for the majority of the sample is considered as an influential factor on investors' investment decisions, which indicates that investment funds are directed towards Islamic environment. In addition, the study found that the investors note that there is only a demand for shares in special companies.

(Ahmed, 2016) study aimed to identify the extent of investment decisions' impact of individual investors in the Egyptian Stock Market on behavioral biases, as well as identify the most important factors of behavioral biases that affect the behavior of investors in the Egyptian Stock Exchange in 2015. The study used the questionnaire as a tool for the study. The study found that there is an impact of behavioral biases, such as (excessive self-confidence, familiarity bias, and bias to investment in the country) on the investors' investment decision in the Egyptian Stock Market. Also, the study found that the impact of biases (excessive optimism and flock behavior) on their investment decisions isn't significant which is contrary to the results of (Shahat et al., 2012) study.

(Al-Rajhi \& Al-Manasy, 2017) study aimed to identify the effect of financial and accounting factors on the prices of shares of Saudi Joint Stock Companies. The study focused on the following factors: (rate of return on shareholders' equity, rate of share from net profit, exchanging rate, ratio of the total liabilities to the total assets, rate of assets rotation and return on total assets). The study sample consisted of 90 Saudi joint stock companies during the period from 2013 to 2014. The study followed content analysis method. The study found that the share of net profit per share, the ratio of total liabilities to total assets, and the rate of assets rotation on stock prices have an effect. In addition, the study found that there is no relationship between the ratio of exchange and shares prices.

(Al-Naggar, 2017) study aimed to explore the behavioral factors affecting the decision-making process for investors. The study targeted the individual investors within the Palestinian capital market. The study used descriptive analytical method and relied on the questionnaire as a tool for study. The valid questionnaires for analysis were 130 questionnaires. The study found that there are four behavioral factors affecting investors' decisions, including the theory of inference, the theory of expectation, market factors, and the flock phenomenon. As, the theory of inference included representation, dependence, high confidence, historical cost, adventure, and availability of bias. While the theory of expectation included avoidance of loss, avoidance of regret, and mental processes. Whereas market factors included price fluctuations, market information, stock price trends in the past, customer preferences, over-reaction to price changes. However the flock phenomenon included the impact of other investors (buying, selling, selecting 
decisions of shares, exchange volume, and the flock speed), and behavioral factors positively affect the performance of investment portfolio.

\subsection{Research Methodology}

The study adopted an inductive method on the theoretical side, an inductive method is to extrapolate researches and previous studies on the research topic, both in the literature of accountancy or in other sciences (Ghareeb, 2006), (Al-Saad, 2007). On the field side, the study used a questionnaire as a study tool, a five-degree Likert cale was used.

A questionnaire is a research tool that is very much applied in various types of educational, psychological, social, economic and other researches (Assaf, 2012). A questionnaire is used as a research tool when the requested information is a personal opinion or viewpoint of the respondent's in a particular issue (Assaf, 2012). A questionnaire can be defined as "an appropriate tool for obtaining information, data and facts linked to a particular reality". (Obidat et al., 2007.104). The study group consists of all individuals investing in the Saudi stock market. The study focused on the shares of companies traded or tradable in the Saudi financial market from individual investors in the Saudi Arabian financial market, and they don't include other securities such as bonds or investment in foreign market shares.

\section{Theoretical Framework}

\subsection{Efficacy and Importance of Financial Market}

The meaning of efficiency in the Stock Market revolves around the ability of the market to assimilate the new information received to the market, and reflect it on prices. It is supposed that in the efficient market, information is available to everyone and all persons are capable either, on their own or through financial analysts and this is done instantly without costs or at a Costless Trading. In this case, the prices will reflect permanently all available information and there will be no profits resulting from the excellence in information acquisition individually. The concept of information efficiency of the market, which means the extent of its response to the new information coming to the market, seems strange and unreasonable. If the efficiency of the market increases, the random price changes increases. The more efficient market is the market in which price changes are completely random and unpredictable because all participants in the market seek to make profits through using their information, which leads to the reflection of this information quickly in the market price of the security in a way that doesn't have the opportunity to make extraordinary profits at the expense of others. However, this does not mean that there is no opportunity to achieve profits or losses. The owner of the security, at the time the information reaches the market, will achieve a profit or capital loss in terms of the changes in the price of the share, but the intention of the inability to achieve extraordinary profits is the incapacity of any trader to exploit an information available to him particularly to obtain the share at a price less than the real price which reflects this information or gets rid of shares at a price that exceeds its real price (Abdullah, 2012). When the financial market is in the required level of efficiency, this increases the efficiency of the performance of companies registered in the market, and new investors are increasingly interested in dealing within the market (Al-Hossan, 2002). From the required characteristics in the financial markets (Capital Market Authority, 2018): efficacy, depth, and breadth; as the market efficacy means that, all information that are available and received, is directly reflected in the price of the stock. While the market can be described as deep if there are many buy and sell orders in a close area around the current market price which means the balance between supply and demand. Conversely, shallow or low-liquidity markets result in a lack of demand or supply and wide fluctuations in price however large markets distinguish with large transactions, as prices aren't changed constantly due to many transactions (as in the deep market), but orders' volumes above and below the current market price are also large (Capital Market Authority, 2018).

The efficacy of the market can be divided into three levels according to the type of information (Fama, 1970) as following:

1. Low level of efficiency, which includes only some information about the historical price, as the current prices reflect the historical information represented in the prices of securities and the volumes of dealings in the market as whole during the previous years.

2. Semi-strong level of efficacy, which includes the information about whether the prices agree with other information in the reports of annual earnings and market shares divisions and the previous prices reflect not only the historical information, but also the current information published and available to all such as financial lists of the company.

3. Strong level of efficacy, which provides information about the investors and stakeholders' acquisition on the information, related to the prices. Available information is fully reflected on the prices and the previous prices reflect 
not only the historical and present information, but also the special information such as the company's undisclosed merger plan.

While, (Ball \& Brownt, 1968) study indicated that the market efficacy determines significantly the adequacy of the sources of data related to it. However, (Jiang, 2017) study showed that capital markets are more efficient and effective when there is better liquidity, frequent exchanging and more changes in returns and higher prices and level in capitalism. The most important factors that hider the market's achieving the required level of efficacy include low communications and information transmitting to all stakeholders, lack of financial analysts and their experiences, small size of market in terms of limited exchanged shares and dealers, as well as prevalence of rumors and speculations, domination on exchange processes, absence of the role of market makers and slowness in the procedures of shares' registration and transfer of their ownership (Al-Hossan, 2002). The importance of stock market for individuals and companies appear to (Yacoub, 2006):

1. Facilitate investment process.

2. Transfer securities to liquidity when needed.

3. Provide investment for individuals and organizations at different terms.

4. Companies' Financing.

5. Companies benefit from savings.

In order for financial markets to achieve their assigned role in allocating savings effectively and directing them towards financing economic projects, there are two essential characteristics should be available including; pricing efficiency and operational efficiency. The efficiency of pricing is referred to as the external efficiency, which means that all information related to securities should be available to all market participants quickly and at a reasonable cost. Operational efficiency is referred to as the internal efficiency, which means the ability of the market to reduce the profit margin, which represents the difference between purchasing and selling price of the security. If the margin between selling and purchasing price is low, operational efficiency increases. This will be achieved only by creating a reasonable balance between supply and demand by achieving a high level of competition which leads to decreasing brokerage costs and reducing the chances of achieving extraordinary profits (Al-Hossan, 2002).

There are several theories that interpret factors that affect the prices of shares, as well as the movement and trend of supply and demand in shares market; these factors are as following (Yacoub, 2006):

- Basic or economic conditions or factors represent some external factors affecting the trend of prices at the long term.

- Technical factors or conditions represent some internal factors affecting the movements of prices at the short term.

\subsection{Types of Financial Markets}

Financial markets are divided as following (Capital Market Authority, 2018):

1. Spot Markets (Quick): It is the market in which the process of selling and purchasing is made quickly.

2. Future Markets: It is the market in which different types of future contracts are exchanged. The example of future markets is Chicago Stock Exchange.

The spot market can be divided into:

1. Cash market: It is the market in which short term financial assets are exchanged such as; treasury bills, depositary certificates, commercial papers and banking acceptances, etc.

2. Capital market: It the market in which long term financial assets are exchanged such as; public bonds, companies bonds and shares, etc. There are two types of the capital market as following:

1. Primary market: It is the financial market in which new securities are enacted and is called the market of new enactments.

2. Secondary market: It is the financial market in which securities are traded between investors. What happens within it is the transfer of the ownership of the security from one investor to another.

\subsection{Emergence of the Saudi Stock Market}

The Saudi stock market started with the establishment of the first Saudi joint stock company in 1935, which was the Arab Automotive Company with a value of 12 million SAR, and the number of shares was 26 thousand shares. The system of companies was issued in 1965, and in 1983, a committee composed of the Ministry of Finance and 
National Economy, the Ministry of Commerce and the Monetary Agency was formed to regulate and develop the performance of the stock market. In 1984, Commercial Banks established Saudi Stock Registration Company, as the company provides the main registration facilities for joint stock companies and equation and set-off all shares operations. The automated equation and set-off system was applied in 1989. In 1990, the Monetary Agency introduced Equity Services \& Information System (ESIS) that provides instant and continuous information about the volume of transactions, sale and purchase orders, shares' distribution, and their prices in the market by companies instantly (Saudi Arabian Monetary Agency, 1997). The importance of the financial market appears in contributing to the economic development through the development of financial savings, raising the level of economic awareness, providing liquidity to investors, financing development projects, predicting the state of the economy and the efficiency of financial and cash policies of the state, as the general indicator of the financial market is the mirror of the economic situation and the efficiency of financial and cash policies of the state, reducing the rates of inflation growth in the economy by directing liquidity to investment instead of consumption, observation the performance of companies, growth and permanence of family businesses and contributing to privatization, as the transferring of public projects to the private sector requires a large and organized market that allows the assimilation of securities for projects to be privatized, diversification sources of debt, attracting foreign investments, and increasing productivity and efficiency of the performance (The Financial Entrepreneurship Program, 2017). It can be said that the financial market in Saudi Arabia appeared with informal starts in the fifties. The situation continued until the government established the basic regulations of the market in 1980s. Under the "Capital Market System" issued by the Royal Decree No. (M/30) on 2/6/1424 Hijri, the Capital Market Authority (CMA) was established on 31/7/2003, which is a governmental agency with financial and administrative independence and directly linked to the Prime Minister. The authority shall supervise the organization and development of the financial market, the issue of regulations, rules and instructions required to implement the provisions of the Capital Market Law in order to provide the appropriate environment for investment in the market, increase the confidence on it, ensure the appropriate disclosure and transparency of the companies registered in the market and protect the securities investors and dealers from illegal acts in the market. The authority has the following powers (Note 2):

- Organize and develop the financial market and improve and develop the methods of systems and entities involved in securities exchange.

- Protect investors from unfair and improper practices that involve fraud, deception, cheat, manipulation, or exchange based on internal information.

- Seek to achieve justice, efficiency, and transparency in securities transactions.

- Develop controls that limit risks associated with securities transactions.

- Develop, regulate, and control the issue and exchange of securities.

- Organize and monitor the activities of entities subject to the supervision of the Capital Market Authority.

- Organize and control the disclosure of information related to securities and its issuers.

\subsection{Development of the Saudi Stock Market}

Saudi Stock Exchange (Tadawul) is a Saudi Closed Joint Stock Company, which is the only authorized entity to engage in listing and exchanging of the securities in the Kingdom. While, the Securities Depository Center Company ("Edaa") is a closed joint stock company which is owned totally to the Saudi Stock Exchange (Tadawul). It is the only entity authorized to practice the processes of deposit, transfer, equation, and set-off securities and register its ownership in accordance with the Capital Market System and related Regulations and Rules. In 2015, Tadawul approved New Automated Exchange System, which was called (NASDAQ'S X-Stream INET) and was the best international platforms for exchange. The exchange of securities listed in the market is made through linking the orders of purchasing and selling together according to the pricing priority and time order of demands through the transactions concluded between the intermediaries on their behalf or on behalf of their customers. While, the used Equation System and Deposit Centre is (NASDAQ Equator \& Edaa Centre), however the supervision system used is (SMARTS) from NASDAQ. Securities identifier is the International Securities Identifying Number (ISIN) (Note 3). Previously, the sectors of companies in Saudi Stock Market (Tadawul) were classified by the way, which doesn't reflect the nature of their activity or the actual sector to which they belong. In addition, the previous classification of (Tadawul) sectors has several obstacles and challenges, as it doesn't depend on international classification standards, there aren't periodic reviews to follow the changes that affect companies' activities, and according to them, the sector to which they belong is modified. In 2008, Tadawul established new standard for classifying the market sectors in keeping with the economic development in the kingdom which is called the Global Industry Classification Standard 
(GICS) which is a universally known classification system applied by the participants in markets, including groups related to investment activities such as, assets managers, mediators and consultants, researchers and shares' markets. The international S\&P and MSCI companies competent in financial information field with the development of international standard for sectors' classification (GICS), as the two companies are leading international companies in providing independent international financial data, indicators' information, and products and services related to guided comparisons. The standard (GICS) distinguishes with that: it is international and applicable to thousands of companies around the world. Also, it's reliable because it is independent and indifferent classification made by two international companies in financial information field, flexible which provides four levels for analysis, as well as it's viable. GICS standard depends on classification system consisted of four levels that include 11 basic sectors (level 1), 24 sectors (level 2), more than 60 sub-sectors (level 3) and more than 150 detailed sectors (level 4). Previously, exchange sectors were divided into 16 basic sectors. While, structuring the new market sectors in exchange includes 20 sectors that represent the second level according to the Global Industry Classification Standard (GICS) as following (Note 4):

\begin{tabular}{llllll}
\hline 1 & Energy & 8 & Media & 15 & Investment and Financing \\
\hline 2 & Basic Materials & 9 & Retaining Luxury Goods & 16 & Insurance \\
\hline 3 & Capital Goods & 10 & Foods Retaining & 17 & Communications \\
\hline 4 & $\begin{array}{l}\text { Professional and } \\
\text { Commercial Services }\end{array}$ & 11 & Foods Production & 18 & Public Facilities \\
\hline 5 & Transport & 12 & Healthcare & 19 & Exchanging Real Estate Funds \\
\hline 6 & Long Term Goods & 13 & Pharmaceutical & 20 & $\begin{array}{l}\text { Management and Development } \\
\text { of Real Estate }\end{array}$ \\
\hline 7 & Consuming Services & 14 & Banks & & \\
\hline
\end{tabular}

Organizational framework of the financial market and related regulatory and organizational agencies (Note 5):

1. Financial Market Authority: It is the authority, which was established under the financial market system and links directly to the Prime Minister. It has the legal personality and financial and administrative independence and has all necessary powers to supervise the organization and development of the financial market.

2. Saudi Arabian Monetary Authority (SAMA): It is considered as the central bank in the Kingdom of Saudi Arabia. It is responsible for organizing the works of commercial banks and currencies, monitoring insurance companies, and financing companies and credit information companies.

3. Ministry of Commerce and Investment: It is responsible for developing and implementing commercial policies. Also, it suggests and applies commercial regulations and rules.

4. General Authority for Investment: It was established for the purpose of localizing and attracting foreign investment, improving and developing the investment environment and raising the level of services.

5. Saudi Organization for Certified Public Accountants (CAOA): It operates under the umbrella of the Ministry of Commerce through reviewing and developing accounting and auditing standards and seeking to develop this profession.

6. General Authority for Charity and Income: It is a public agency affiliated to the Ministry of Finance, which is responsible for collecting and raising charity, and collecting and raising the tax from those subject to it.

The Saudi Arabian Monetary Authority applied several procedures in order to protect the investors (Saudi Arabian Monetary Authority, 2017):

1. New Period for Equation $(\mathrm{T}+2)$ which means the period between the execution of the transaction and the registration of the transfer of the security ownership and the payment of the transaction value, which is estimated at two working days and was implemented in 2017. Previously, the following mechanism of equation was implemented $(T+0)$, where the transactions were settled on the same day. There are several objectives to be achieved by modifying the period for the equation of securities transactions for two working days, including raising the level of the protection of investors' assets, verifying the validity of the transaction and dealing with errors, if any, 
harmonizing international standards applied in other markets in terms of the equation procedures, which increases the opportunities of listing the Saudi Market in the Global Markets Indicators.

2. The parallel market (growth), which was launched in 2017, and was considered as a market with lower listing requirements. It was also an alternative platform for companies to be listed, and companies listed on the parallel market can move to the main market after submitting a new file to the Capital Market Authority. One of the objectives of establishing the parallel market (growth) is an additional source for financing companies and increasing the capital, increasing the variety of available investment instruments and deepening the Saudi financial market.

The beginning of the emergence of the Saudi stock market back to the mid-thirties when the Arab Automotive Company was established, as the first Saudi joint stock company. However, the actual interest to invest in the market began after the first oil boom in 1973, as the number of joint stock companies during that period reached 14 companies and the establishment of new joint stock companies after the second oil boom during the period 1976-1982, where the number of companies reached 48 companies in 1985 and in 2003 the number of companies reached 69 companies (Al-Hossan, 2002). The following table shows the historical development of stock market indicators in the period (from 1985 to 2004):

Table 1

\begin{tabular}{llllll}
\hline Period & $\begin{array}{l}\text { Number } \\
\text { Exchanged } \\
\text { Shares (Million) }\end{array}$ & $\begin{array}{l}\text { Value } \\
\text { Exchanged Shares } \\
\text { (Million) }\end{array}$ & $\begin{array}{l}\text { of } \\
\text { Shares (Billion) }\end{array}$ & $\begin{array}{l}\text { Number } \\
\text { Transactions }\end{array}$ & $\begin{array}{l}\text { Public Indicator } \\
\text { "Basic Year 1985" }\end{array}$ \\
\hline 1985 & 4 & 760 & 67 & 7842 & 690.88 \\
\hline 1986 & 5 & 831 & 63 & 10833 & 646.03 \\
\hline 1987 & 12 & 1686 & 73 & 23267 & 780.64 \\
\hline 1988 & 15 & 2037 & 86 & 41960 & 892 \\
\hline 1989 & 15 & 3364 & 107 & 110030 & 1086.83 \\
\hline 1990 & 17 & 4403 & 97 & 85298 & 979.8 \\
\hline 1991 & 31 & 8527 & 181 & 90559 & 1765.24 \\
\hline 1992 & 35 & 13699 & 206 & 272075 & 1888.65 \\
\hline 1993 & 60 & 17360 & 198 & 319582 & 1793.3 \\
\hline 1994 & 152 & 24871 & 145 & 357180 & 1282.9 \\
\hline 1995 & 117 & 23227 & 153 & 291742 & 1367.6 \\
\hline 1996 & 138 & 25397 & 172 & 283759 & 1531 \\
\hline 1997 & 312 & 62060 & 223 & 460056 & 1957.8 \\
\hline 1998 & 293 & 51510 & 160 & 376617 & 1413.1 \\
\hline 1999 & 528 & 56578 & 229 & 438226 & 2028.53 \\
\hline 2000 & 555 & 65292 & 255 & 498135 & 2258.29 \\
\hline 2001 & 691 & 83602 & 275 & 605035 & 2430.11 \\
\hline 2002 & 1736 & 133787 & 281 & 1033669 & 2518.08 \\
\hline 2003 & 5566 & 596510 & 590 & 3763403 & 4437.58 \\
\hline 2004 & 10298 & 1773859 & 1147 & 13319523 & 8206.23 \\
\hline $5045:(T 201964$ & & & \\
\hline
\end{tabular}

Source: (Tadawul, 2005, p. 42)

\subsection{The Collapse of the Saudi Stock Market}

By the end of 2003, the index closed at 4437.6 points, up from the last close of 2518.1 points in 2002. In addition, the index rose by $84 \%$ in 2004 and by $103.7 \%$ in 2005 . The market trading value showed similar growth and jumped 
from $\$ 68$ billion in 2000 to nearly $\$ 646$ billion by the end of 2005 . This enormous increase was not limited to Saudi Arabia but included all Gulf Cooperation Council stock markets. There have been surprisingly huge amounts of cash liquidity across the region, possibly because of the emergence of some fears after the September 11 attacks in the United States, prompting the wealthy Arabs to reclaim their investments from Western markets and invest them domestically. In addition, oil prices doubled between 2000 and 2005 due to increasing demand, which increased oil revenues. As a result, the state has repaid its debts and thus increased cash liquidity in banks, which enabled the state to give more loans to citizens wishing to invest in the stock market. In the Saudi market during that period, there are rarely investment options other than investment in the stock market (Lerner et al., 2017).

Any financial market in the world is exposed to cases of decline, which experts in the financial markets call profit-taking. The drop in this case ranges from 5\% to $10 \%$. If the drop is about $15 \%$ then it will be called market corrections and the percentage may reach $25 \%$ if the correction is severe (Yacoub, 2006).

The time period for profit-taking and correction is relatively short, usually from one to two weeks at the highest estimate and this decline includes most of the market companies. However, when the price index in the market is dropped to more than $50 \%$ in less than five months, then this sharp decline is accompanied by a fall for the leading companies in the market, which control the market price index and a collapse of the price of most market companies in different sectors. This is called by many experts the collapse of the market, which occurred in the Saudi market in the period from 25 February 2006 and the decline rate, was about $60.7 \%$ until 3 December 2006. The Saudi stock market crisis occurred in light of strong economic indicators, political stability and good performance for most sectors of the financial market, especially banks, industrial companies, cement companies, and telecommunications (Yacoub, 2006).

It was not encouraging, the individual traders accounted for more than $95 \%$ of the daily trading percentage. Personal debt levels rose significantly between 2002 and 2006. Loans (for other purposes) increased by about five times, which are not related to the purchase of real estate or durable goods, from $7.8 \$$ billion in 2002 to $36 \$$ billion by 2005 . In addition, the adoption by the Capital Market Authority (CMA) of the immediate settlement cycle $(\mathrm{T}+0)$ instead of the transaction settlement mechanism within three working days $(\mathrm{T}+3)$ or two business days $(\mathrm{T}+2)$, has led to an increase in the volume of random trading in the market and Some government officials and analysts continued to issue statements or reports until 2005 encouraging citizens to invest in the market. In addition, the Kingdom did not have enough experience to deal with this rise or collapse that followed. The Capital Market Authority (CMA), the regulator of trading, was not established until 2003. Investors in investment funds called for redemption, forcing them to sell their units in the declining market. However, Saudi Arabian Monetary Agency sought to meet redemption requests by investing in those funds without further downward pressure on markets (Lerner et al., 2017).

The most important reasons for the rise in of the Saudi stock market index from 1999 to 2005 was: the rise in profits of many companies, increased confidence of dealers in the domestic market, the decline rates of interest on deposits in banks, increasing the number of dealers in the market and the small number of companies. Because of the unjustified rise of the stock market index, the market value of some of the losing companies' shares increased compared to the companies that achieved positive results. The market value of some companies increased. As soon as the company enters the capital market, its market value is more than ten times its nominal value even before the company operates. A large number of citizens entered the stock market where the number of portfolios in the market was more than 3 million portfolios. State ownership of many large-cap stocks affects the volume of stock supply. There were many rumors in the market that had an impact on the market index. The Saudi banks manage many financial portfolios in shares for their account and for others, as well as the presence of many companies in the management of regular and irregular portfolios, many of which are concentrated in random speculation (Yacoub, 2006).

The Capital Market Authority's efforts to limit the rapid rise included the prohibition of buying shares on the market manipulators but not preventing them from selling, prevention of listed companies from trading in shares of other joint stock companies, unless their regulations permit it. The increase in price action, which had little effect due to the high peaks reached by the market, which reduced the volatility to 5\% instead of $10 \%$. The Capital Market Authority later announced that non-Saudi residents would be allowed to invest directly in the stock market rather than through investment funds. However, the market index continued to decline. The Capital Market Authority also announced a reduction in the nominal value of the share from 50 SR to $10 \mathrm{SR}$, thus dividing the shares of listed companies by five shares per share (Lerner et al., 2017).

The collapse of the Saudi stock market was not a unique experience. Historically, some countries have suffered from price collapse in diversified assets, real estate, railways, or stocks. For example, in China in 2015, there were a series 
of stock market collapses similar to those in Saudi Arabia in 2006, when the Chinese market index (Shanghai Composite Index) lost about $30 \%$ of its value in less than a month (Lerner et al., 2017).

The General Index of the Saudi Stock Market (TASI) from July 2004 until January 2007:

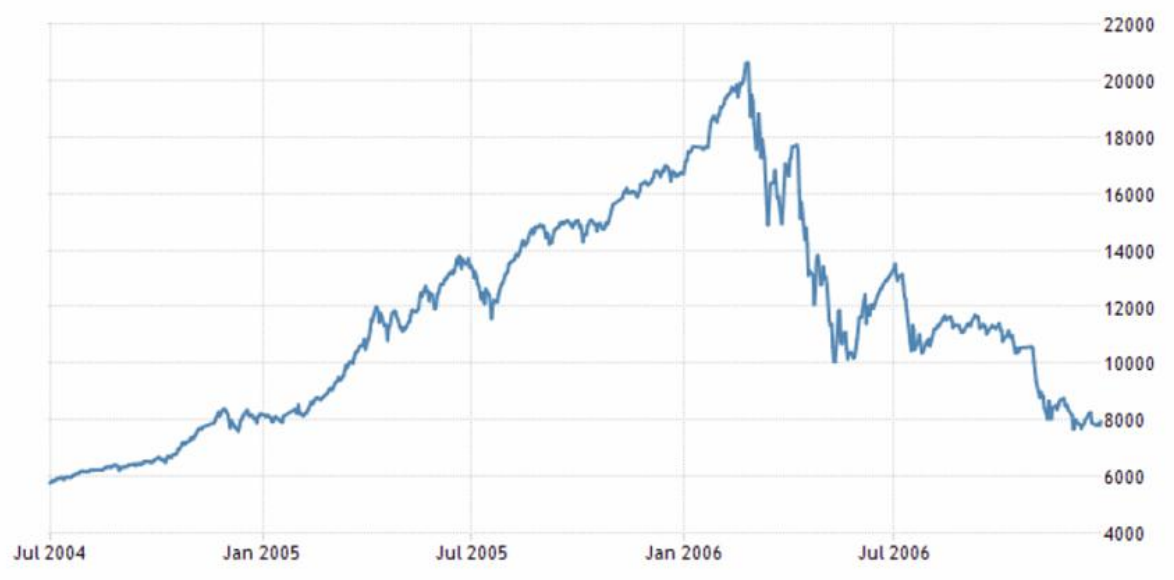

Figure 1

Source: (Lerner et al., 2017). Copied from: Saudi Stock Exchange. www.tradingeconomics.com

The main reasons that led to the crisis of the Saudi stock market (Yacoub, 2006) include the following:

- The expansion of loans provided by commercial banks to individuals and companies for trading and investing in the stock market.

- The uncontrolled performance of the investment funds from banks.

- The high interest rates in banks.

- The large number of Initial Public Offerings (IPOs).

- The unjustified rise in shares of many market companies.

- The cancellation of dealing with Saudi Rial quarters.

- The reduction of the oscillation rate from $10 \%$ to $5 \%$.

- The prevention of the entry of sales orders for more than one day.

- The announcement of the suspension of some brokers.

- Technical failures that occurred in the trading system more than once.

- Psychological reasons.

- False rumors.

- The weakness of the legislative and regulatory frameworks of the Capital Market Authority.

- Many traders lack the dealing culture in the stock market.

\subsection{Saudi Stock Market After the Collapse}

The following Tables 1, 2 issued by the Capital Market Authority (Tadawul), show the statistics of the stock market for 10 years. In Table 2 we find that the quantity traded in the capital market using the equation of the arithmetic average has increased in general by $1.75 \%$. While on the other hand, the value of shares traded decreased by $-0.82 \%$. Table 3 shows an increase in market capitalization, with a rise of $6.89 \%$, while the average number of transactions decreased to $-3.37 \%$.

Stock market statistics for 10 years from 2008 until 2017 (Note 7). 
Table 2

\begin{tabular}{|c|c|c|c|c|}
\hline Year & $\begin{array}{l}\text { Volume } \\
\text { (millions) }\end{array}$ & $\begin{array}{l}\text { Change } \\
\text { Percentage }\end{array}$ & $\begin{array}{l}\text { Value of shares traded } \\
\text { (millions) }\end{array}$ & $\begin{array}{l}\text { Change } \\
\text { Percentage }\end{array}$ \\
\hline 2008 & 61,147 & --- & $1,962,945.58$ & --- \\
\hline 2009 & 57,074 & $-6.66 \%$ & $1,264,011.29$ & $-35.61 \%$ \\
\hline 2010 & 33,786 & $-40.80 \%$ & $759,184.48$ & $-39.94 \%$ \\
\hline 2011 & 48,032 & $42.16 \%$ & $1,098,836.03$ & $44.74 \%$ \\
\hline 2012 & 78,047 & $62.49 \%$ & $1,929,318.27$ & $75.58 \%$ \\
\hline 2013 & 50,706 & $-35.03 \%$ & $1,369,665.79$ & $-29.01 \%$ \\
\hline 2014 & 66,527 & $31.20 \%$ & $2,146,511.90$ & $56.72 \%$ \\
\hline 2015 & 63,617 & $-4.37 \%$ & $1,660,622.05$ & $-22.64 \%$ \\
\hline 2016 & 64,481 & $1.36 \%$ & $1,156,987.08$ & $-30.33 \%$ \\
\hline 2017 & 43.297 & $-32.85 \%$ & $836,275.13$ & $-27.72 \%$ \\
\hline
\end{tabular}

Table 3

\begin{tabular}{lllll}
\hline Year & $\begin{array}{l}\text { Market } \\
\text { (billions) }\end{array}$ & $\begin{array}{c}\text { Value } \\
\text { Percentage }\end{array}$ & $\begin{array}{l}\text { Change } \\
\text { Number of transactions }\end{array}$ & $\begin{array}{l}\text { Change } \\
\text { Percentage }\end{array}$ \\
\hline 2008 & 924.53 & --- & $52,135,929$ & --- \\
\hline 2009 & 1195.51 & $29.31 \%$ & 36.458 .326 & $-30.07 \%$ \\
\hline 2010 & 1325.39 & $10.86 \%$ & $19,536,143$ & $-46.42 \%$ \\
\hline 2011 & 1270.84 & $-4.12 \%$ & 25.546 .933 & $30.77 \%$ \\
\hline 2012 & 1400.34 & $10.19 \%$ & $42,105,048$ & $64.81 \%$ \\
\hline 2013 & 1752.86 & $25.17 \%$ & 28.967 .694 & $-31.20 \%$ \\
\hline 2014 & 1812.89 & $3.42 \%$ & $35,761,091$ & $23.45 \%$ \\
\hline 2015 & 1579.06 & $-12.90 \%$ & $30,444,203$ & $-14.87 \%$ \\
\hline 2016 & 1681.95 & $6.52 \%$ & $27,273,685$ & $-10.41 \%$ \\
\hline 2017 & 1689.60 & $0.45 \%$ & $21,895,281$ & $-19.72 \%$ \\
\hline
\end{tabular}

In 2016, Saudi Arabia's financial market exposed to liquidity and volatility risks due to various economic-related factors that led to some pressure on market activities. In addition, the economic slowdown and the contraction of investment in 2016 led to a decline in financial market activities. The current status of the financial market remains good despite the many challenges facing the Saudi economy due to declining oil revenues, coupled with oil price fluctuations that added the pressure on market stability. In addition, the government reforms affect directly the liquidity of the market. However, the market value of stocks rises (Financial Stability Report, 2017).

The Saudi financial market ranks the 25th as the largest stock market in the World Federation of exchanges. The market capitalization reached 451 US billions by the end of 2017 . Net income grew by 129.8 million SR by 31 December 2017 with an increase of $543 \%$ in comparison with the previous year. In addition to an increase in revenues by $74 \%$ and a total of 545.4 million SR compared to 2016. In addition to achieving the following operational achievements: the adoption of the Global Industry Classification Standard, the modification of the time frame for the settlement of quoted securities transactions $(\mathrm{T}+2)$, the enabling of lending and borrowing of listed securities companies as well as the covered short sale. As well as the formal announcement of the conversion of the Securities Depository Center "Edaa" to an independent subsidiary, and the conclusion of the agreement of the post-trading services with the NASDAQ (Note 8), and the launch of the parallel market for Tadawul "NOMU." The total market value is 1.689 .60 billion SR, with a compound annual growth rate of $0.45 \%$. While the total value of trading is 836.28 and the number of listed companies is 188 companies in 20 sectors (The Annual Report, 2017). 
Summary of Financial Performance of Saudi Stock Exchange (Tadawul):

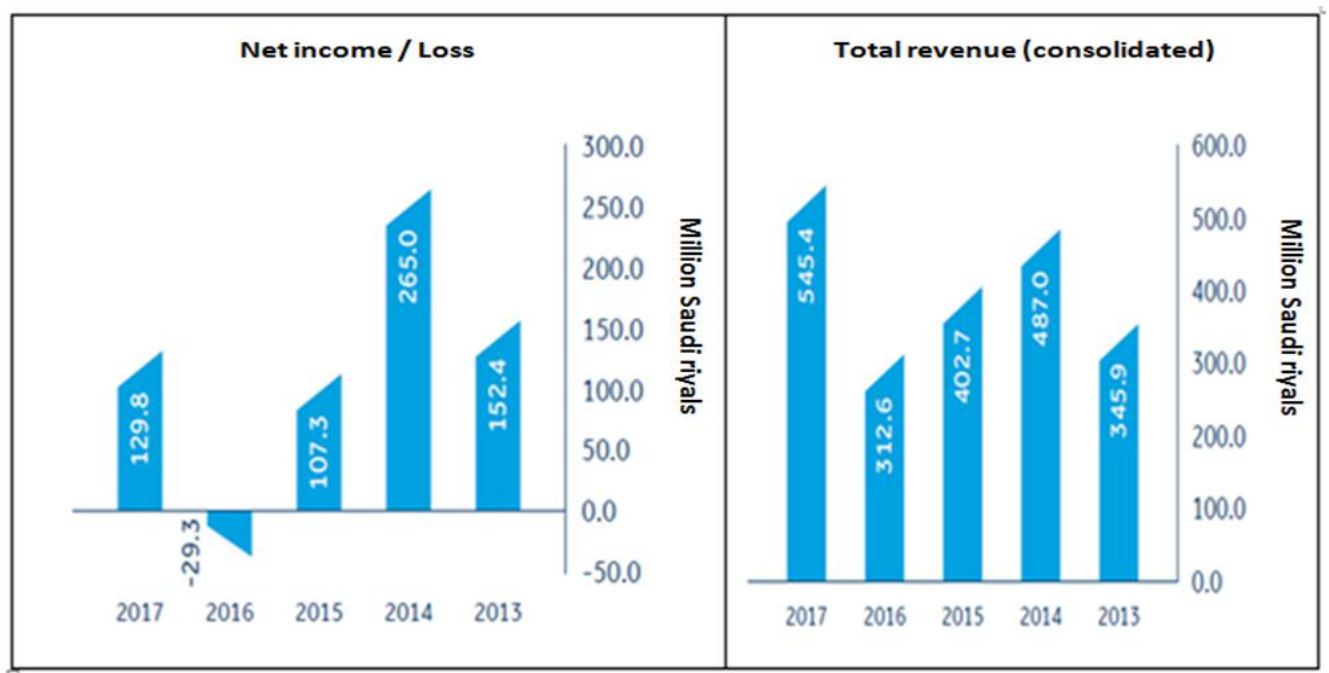

Figure 2

Source: Saudi Stock Exchange "Tadawul" (The Annual Report, 2017. p.5)

The Saudi stock market aims to become the main market in the Middle East by 2020, increase the foreign investment ratio above $15 \%$ of the market capitalization, grow deeper, attract the developing companies, increase the number of the listed companies to exceed 250 companies, encourage companies to contribute to the listing and establishing an investment funds and asset management companies that enable citizens to invest their savings in the shares of listed companies or investment products, which contributes to increasing investment opportunities, increase employment rates and reduce unemployment rates. The objectives of the strategic plan that the Saudi stock Market seeks to implement include (The Financial Entrepreneurship Program, 2017):

- Facilitating financing by deepening the financial market and enhancing its role in the formation of funds, developing the stock market and debt instruments, and enhancing the role of the investment funds in financing the national economy.

- Stimulating the investment by supporting asset management growth and promoting institutional investment, raising market attractiveness to foreign investors, and diversifying investment products.

- Enhancing the confidence by strengthening the regulatory environment of the financial market, enhancing stability in the financial market, raising the level of governance in the financial market, and raising the level of transparency and disclosure.

- Building the abilities by supporting and developing of licensed persons, raising awareness of the role of the Capital Market Authority and the investment financial culture in the financial market, and building capacity of participants in the financial market.

\section{Practical Framework}

It has already been pointed out that the aim of the research is to identify the affecting factors (analysis and financial ratios, the history and reputation of the company, dividend distributions, company founding date, company size, recommendations and opinions of analysts, the nature of the company's activity) on the decision of investment in the Saudi stock market, and to achieve the objective of the research ,130 questionnaires were distributed, of which 128 questionnaires are valid for analysis on the availability sample. A sample refers to a fraction, a small section, or a limited set of cases or answers that are selected for the purpose of identifying the characteristics of the total (population) to which that sample belongs. The study was applied to a non-random sample and the availability sample is one of the most significant types which is the sample by which available individuals are tested in front of a researcher (Shiraz, 2015). 


\subsection{Sample Description: Personal Characteristics of the Research Sample}

According to gender: The sample was distributed according to gender with $68 \%$ for males and $32 \%$ for females of the total sample of 128 items, as shown in Table 4.

Table 4. Sample distribution according to gender variable

\begin{tabular}{lll}
\hline Gender & Frequency & percentage \\
\hline Males & 87 & $68 \%$ \\
\hline Females & 41 & $32 \%$ \\
\hline Total & 128 & $100 \%$ \\
\hline
\end{tabular}

According to age group: The sample was distributed according to age groups to $40.6 \%$ for the age group (from 30 years-less than 40 years), and by $37.5 \%$ for the age group (under 30 years), with ages ranging between (40 - under 50 years by $14.1 \%$, and the age group (50 years and over) was $7.8 \%$ as shown in table 5 , that the sample was distributed to all age groups and that the young age group was the majority.

Table 5. Sample distribution according to age variable

\begin{tabular}{lll}
\hline Age group & Frequency & Percentage \\
\hline Under 30 years & 48 & $37.50 \%$ \\
\hline From 30 years -less than 40 years & 52 & $40.60 \%$ \\
\hline From 40 years-less than 50 years & 18 & $14.10 \%$ \\
\hline From 50 years and over & 10 & $7.80 \%$ \\
\hline Total & 128 & $100 \%$ \\
\hline
\end{tabular}

According to the scientific qualification variable: the results in Table 6 indicated that $61.7 \%$ of the total sample had a bachelor's degree, followed by $21.9 \%$ of the sample had a secondary school certificate and lower, then a master's degree had $14.8 \%$, and only $1.6 \%$ of the sample had a doctoral degree, thus the sample includes all qualifications that indicates its representation of the population.

Table 6. Sample distribution according to scientific qualification variable

\begin{tabular}{lll}
\hline Academic qualification & Frequency & Percentage \\
\hline Secondary school or lower & 28 & $21.90 \%$ \\
\hline Bachelor's degree & 79 & $61.70 \%$ \\
\hline Master's degree & 19 & $14.80 \%$ \\
\hline PhD & 2 & $1.60 \%$ \\
\hline Total & 128 & $100 \%$ \\
\hline
\end{tabular}

According to the variable of circulation period : The results showed that the sample was distributed according to the period of circulation, traders for a period of (less than a year) had $54.7 \%$ of the total sample and they are the latest in the decision of circulation and investment for the time being, and hence their views of future importance in investment and circulation, then traders for a circulation period of ( one year-less than 5 years) and (more than 10 years) with $18.7 \%$ of the total sample, the lowest percent of the sample for traders ( from 5 years-less than 10 years) with $7.9 \%$ of the total sample, as shown in Table 7. 
Table 7. Distribution of sample according to circulation period variable

\begin{tabular}{lll}
\hline Period of circulation & Frequency & Percentage \\
\hline Less than one year & 70 & $54.70 \%$ \\
\hline from one year-less than 5 years & 24 & $18.70 \%$ \\
\hline 5 years-less than 10 years & 10 & $7.90 \%$ \\
\hline More than 10 years & 24 & $18.70 \%$ \\
\hline Total & 128 & $100 \%$ \\
\hline
\end{tabular}

\subsection{Tests of Reliability and Stability}

An exploratory sample was applied to investors to verify the reliability and stability of the research tool (a questionnaire) before the application. The results were as follows:

1. Reliability: the reliability of the content where correlation coefficients were calculated between an item and the overall degree of the axis to which it belongs as shown in Table 8 , as well as the overall degree of the axes with the overall degree of the questionnaire, as illustrated in Table 9 The results were as follows:

Table 8. Correlation coefficients and the overall degree of the axis to which it belongs

\begin{tabular}{llll}
\hline Item & $\begin{array}{l}\text { correlation coefficient with overall } \\
\text { degree of axis to which it belongs }\end{array}$ & Item & $\begin{array}{l}\text { correlation coefficient with overall } \\
\text { degree of axis to which it belongs }\end{array}$ \\
\hline 1 & $* * 0.80$ & 17 & $* * 0.79$ \\
\hline 2 & $* * 0.68$ & 18 & $* * 0.74$ \\
\hline 3 & $* * 0.88$ & 19 & $* * 0.78$ \\
\hline 4 & $* * 0.76$ & 20 & $* * 0.71$ \\
\hline 5 & $* * 0.44$ & 21 & $* * 0.90$ \\
\hline 6 & $* * 0.72$ & 22 & $* * 0.75$ \\
\hline 7 & $* * 0.73$ & 23 & $* * 0.86$ \\
\hline 8 & $* * 0.76$ & 24 & $* * 0.89$ \\
\hline 9 & $* * 0.77$ & 25 & $* * 0.78$ \\
\hline 10 & $* * 0.64$ & 26 & $* * 0.41$ \\
\hline 11 & $* * 0.69$ & 27 & $* * 0.52$ \\
\hline 12 & $* * 0.86$ & 28 & $* * 0.70$ \\
\hline 13 & $* * 0.92$ & 29 & $* * 0.56$ \\
\hline 14 & $* * 0.81$ & 30 & $* * 0.64$ \\
\hline 15 & $* * 0.82$ & 31 & $* * 0.38$ \\
\hline 16 & $* * 0.83$ & 32 & $* * 0.79$ \\
\hline
\end{tabular}

$* *$ Indicative at the significance level of 0.01 
Table 9. Correlation coefficients between the axes and the overall degree of the questionnaire

\begin{tabular}{lc}
\hline Axes & $\begin{array}{c}\text { Correlation } \\
\text { overall degree of questionnaire }\end{array}$ \\
\hline $\begin{array}{l}\text { First axis: a relationship between the analysis, financial ratios and the decision } \\
\text { of investment. }\end{array}$ & $* * 0.57$ \\
\hline $\begin{array}{l}\text { Second axis: a relationship between the reputation, history of the company and } \\
\text { the decision of investment. }\end{array}$ & $* * 0.74$ \\
\hline $\begin{array}{l}\text { Third axis: a relationship between dividends and the decision of investment. } \\
\text { Fourth axis: a relationship between the company's founding date and the }\end{array}$ & $* * 0.77$ \\
\hline decision of investment. & $* * 0.76$ \\
\hline $\begin{array}{l}\text { Fifth axis: a relationship between the company's size and the decision of } \\
\text { investment. }\end{array}$ & \\
\hline $\begin{array}{l}\text { Sixth axis: a relationship between the recommendations and opinions of } \\
\text { analysts and the decision of investment. }\end{array}$ & \\
\hline $\begin{array}{l}\text { Seventh axis: a relationship between the nature of the company's activity and } \\
\text { the decision of investment }\end{array}$ &
\end{tabular}

** Indicative at the significance level of 0.01

The data in the previous tables show that the questionnaire enjoys a high degree of reliability, in case all the correlation coefficients are indicative at a significance level of 0.01 , with the highest coefficient of the axis of the relationship between the company's founding date and the decision of investment of (0.77) and the lowest of the relationship between the nature of the company's activity and the decision of investment of $(0.52)$.

2. Stability: The stability coefficients were calculated using Cronbach's alpha coefficient to calculate the internal consistency of the items in each axis and the results were as shown in Table 10:

Table 10. Cronbach's alpha coefficients of stability of questionnaire axes

\begin{tabular}{llc}
\hline Axes & No. of items & Alpha coefficient \\
\hline $\begin{array}{l}\text { First axis: a relationship between the analysis, financial ratios and the } \\
\text { decision of investment. }\end{array}$ & 0.79 \\
\hline $\begin{array}{l}\text { Second axis: a relationship between the reputation, history of the } \\
\text { company and the decision of investment. }\end{array}$ & 0.82 \\
\hline $\begin{array}{l}\text { Third axis: a relationship between dividends and the decision of } \\
\text { investment. }\end{array}$ & 0.74 \\
\hline $\begin{array}{l}\text { Fourth axis: a relationship between the company's founding date and } \\
\text { the decision of investment. }\end{array}$ & 0.67 \\
\hline $\begin{array}{l}\text { Fifth axis: a relationship between the company's size and the decision } \\
\text { of investment. }\end{array}$ & 4 & 0.74 \\
\hline $\begin{array}{l}\text { Sixth axis: a relationship between the recommendations and opinions } \\
\text { of analysts and the decision of investment. }\end{array}$ & 4 \\
\hline $\begin{array}{l}\text { Seventh axis: a relationship between the nature of the company's } \\
\text { activity and the decision of investment }\end{array}$ & 6 & 0.81 \\
\hline Total items of a questionnaire & 32 & 0.88 \\
\hline
\end{tabular}

The data in Table 10 show that the stability coefficients of axes of a questionnaire have an unacceptable to high degree, ranging from (0.67 to 0.82 ) with the highest coefficient of the axis of the relationship between the reputation and history of the company and the decision of investment, and the lowest of the relationship between the company's founding date and the decision of investment, and the stability factor of the total items was about (0.88), which is a high coefficient. 


\subsection{Statistical Tests: The Following Statistical Tests Have Been Applied}

- Frequencies and percentages of investors' responses to a questionnaire's items.

- Arithmetic averages and standard deviation of the performance of individuals on a questionnaire's items to determine the consistency and variation in response among them.

- Rankings to determine the rank for each item according to an arithmetic average degree.

- Differences between the characteristics of the sample members and the response on axes of a questionnaire using $\mathrm{T}$ - tests of the differences between two independent samples in case of the gender variable, and one-way analysis of variance of the differences in the response on the axes according to the variable of an academic qualification, age group and period of circulation.

Table 11 shows the classification of averages degrees according to the performance of the sample members in categories as follows:

Table 11. Classification of arithmetic averages

\begin{tabular}{ll}
\hline Classification & Category \\
\hline Totally agree. & $5.00-4.24$ \\
\hline Agree & $4.23-3.43$ \\
\hline Neutral & $3.42-2.62$ \\
\hline Not agree & $2.61-1.81$ \\
\hline Not very agree & $1.80-1.00$ \\
\hline
\end{tabular}

Frequencies and percentages of the sample's opinions were also found on each axis of the study to determine the degree of agreement of the sample members, the results were as indicated on the following table:

The First Axis: A Relationship Between the Analysis, Financial Ratios and the Decision of Investment.

Table 12. Frequencies, percentages, arithmetic means, standard deviations, and rankings of items for the first axis

\begin{tabular}{|c|c|c|c|c|c|c|c|c|c|}
\hline \multirow[b]{2}{*}{ Item } & \multicolumn{5}{|c|}{ Degree of agreement } & \multirow[b]{2}{*}{ 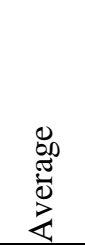 } & \multirow[b]{2}{*}{$\begin{array}{l}\text { Standard } \\
\text { deviation }\end{array}$} & \multirow[b]{2}{*}{ 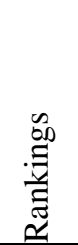 } & \multirow[b]{2}{*}{$\begin{array}{l}0 \\
0 \\
0 \\
0 \\
\tilde{0} \\
\underline{0}\end{array}$} \\
\hline & $\begin{array}{l}\text { Tot } \\
\text { ally } \\
\text { agre } \\
\mathrm{e}\end{array}$ & 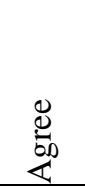 & $\begin{array}{l}\bar{\pi} \\
\stackrel{\Xi}{0} \\
Z\end{array}$ & $\begin{array}{l}\text { Not } \\
\text { agree }\end{array}$ & $\begin{array}{l}\text { Not } \\
\text { very } \\
\text { agree }\end{array}$ & & & & \\
\hline \multicolumn{10}{|c|}{ First axis: a relationship between the analysis and financial ratios and investment decision-making } \\
\hline \multirow{2}{*}{$\begin{array}{l}\text { 1. Making investment decision after } \\
\text { analyzing the company's financial } \\
\text { statements }\end{array}$} & 51 & 40 & 20 & 9 & 8 & \multirow{2}{*}{3.91} & \multirow{2}{*}{1.18} & \multirow{2}{*}{5} & \multirow{2}{*}{ Agree } \\
\hline & 39.8 & 31.3 & 15.6 & 7.0 & 6.3 & & & & \\
\hline \multirow{2}{*}{$\begin{array}{l}\text { 2. Taking care to know the liquidity ratio } \\
\text { before making investment decision }\end{array}$} & 56 & 42 & 18 & 9 & 3 & \multirow{2}{*}{4.08} & \multirow{2}{*}{1.03} & \multirow{2}{*}{3} & \multirow{2}{*}{ Agre } \\
\hline & 43.8 & 32.8 & 14.1 & 7.0 & 2.3 & & & & \\
\hline \multirow{2}{*}{$\begin{array}{l}\text { 3. Taking care to know a reduplicated } \\
\text { profitability before making investment } \\
\text { decision }\end{array}$} & 45 & 49 & 23 & 4 & 7 & \multirow{2}{*}{3.94} & \multirow{2}{*}{1.07} & \multirow{2}{*}{4} & \multirow{2}{*}{ Agree } \\
\hline & 35.2 & 38.2 & 18.0 & 3.1 & 5.5 & & & & \\
\hline \multirow{2}{*}{$\begin{array}{l}\text { 4. Taking care to know the ratio of the } \\
\text { company's debt before making } \\
\text { investment decision }\end{array}$} & 60 & 35 & 23 & 5 & 5 & \multirow{2}{*}{4.09} & \multirow{2}{*}{1.07} & \multirow{2}{*}{2} & \multirow{2}{*}{ Agree } \\
\hline & 46.9 & 27.3 & 18.0 & 3.9 & 3.9 & & & & \\
\hline \multirow{2}{*}{$\begin{array}{l}\text { 5. Making investment decision if the } \\
\text { company's financial indicators were good }\end{array}$} & 57 & 55 & 11 & 5 & 0 & \multirow{2}{*}{4.28} & \multirow{2}{*}{1.78} & \multirow{2}{*}{1} & \multirow[b]{2}{*}{ Agre } \\
\hline & 44.5 & 43.0 & 8.7 & 3.9 & 0.0 & & & & \\
\hline Overall average of axis & & & & & & & 4.06 & 1.03 & Agree \\
\hline
\end{tabular}


The results of Table 12 generally indicate, according to the sample, that there is a significant correlation between the analysis, financial ratios of the company and the decision of investment and circulation, where the sample members generally agree according to a degree of the overall arithmetic average of the axis, which amounted to about (4.06) and a standard deviation of about (1.03), meaning agreement of the sample members on that relationship, the highest items had a very high degree of agreement in an item of (making investment decision if the company's financial indicators were good) with an arithmetic average of about (4.28) and a standard deviation of (1.78), while the rest of the items were all agreed by the sample members where an item of ( taking care to know the ratio of the company's debt before making investment decision) with an arithmetic average of (4.09) and a standard deviation of (1.07), followed by an item of (taking care to know the liquidity ratio before making investment decision) with an arithmetic average of (4.08) and a standard deviation of (1.03), then an item of (taking care to know the ratio of the company's debt before making investment decision) with an arithmetic average of (3.94), and a standard deviation of (1.07), finally an item of (making investment decision after analyzing the company's financial statements) with an arithmetic average of (3.91) and a standard deviation of (1.18). This suggests that the analysis of the company's financial ratios in analyzing the company's financial statements is an encouraging investment decision among investors.

The Second Axis: A Relationship Between the Reputation and History of the Company and Investment DecisionMaking.

Table 13. Frequencies, percentages, arithmetic averages, standard deviations and rankings of the second axis items

\begin{tabular}{|c|c|c|c|c|c|c|c|c|c|}
\hline \multirow[b]{2}{*}{ Item } & \multicolumn{5}{|c|}{ Degree of agreement } & \multirow[b]{2}{*}{ 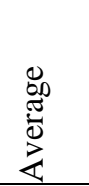 } & \multirow[b]{2}{*}{$\begin{array}{l}\text { Standard } \\
\text { deviation }\end{array}$} & \multirow[b]{2}{*}{ 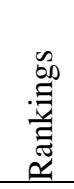 } & \multirow[b]{2}{*}{ 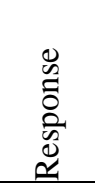 } \\
\hline & $\begin{array}{l}\text { Totally } \\
\text { agree }\end{array}$ & Agree & Neutral & $\begin{array}{l}\text { Not } \\
\text { agree }\end{array}$ & $\begin{array}{l}\text { Not } \\
\text { very } \\
\text { agree }\end{array}$ & & & & \\
\hline \multicolumn{10}{|c|}{$\begin{array}{l}\text { Second axis: a relationship between the reputation and history of the company and investment decision } \\
\text { making }\end{array}$} \\
\hline \multirow{2}{*}{$\begin{array}{l}\text { 1. Making sure to invest in } \\
\text { companies with a good } \\
\text { reputation }\end{array}$} & 72 & 35 & 12 & 7 & 2 & \multirow{2}{*}{4.31} & \multirow{2}{*}{0.96} & \multirow{2}{*}{2} & \multirow{2}{*}{$\begin{array}{l}\text { Very } \\
\text { agree }\end{array}$} \\
\hline & 56.3 & 27.3 & 9.4 & 5.5 & 1.5 & & & & \\
\hline \multirow{2}{*}{$\begin{array}{l}\text { 2. No investment decision } \\
\text { made before studying the } \\
\text { company's situation in the } \\
\text { past }\end{array}$} & 42 & 31 & 36 & 17 & 2 & \multirow[b]{2}{*}{3.73} & \multirow[b]{2}{*}{1.10} & \multirow[b]{2}{*}{5} & \multirow[b]{2}{*}{ Agree } \\
\hline & 32.8 & 24.2 & 28.1 & 13.3 & 1.6 & & & & \\
\hline \multirow{2}{*}{$\begin{array}{l}\text { 3. Taking care to know the } \\
\text { financial situation of the } \\
\text { company before making } \\
\text { investment decision }\end{array}$} & 69 & 42 & 11 & 4 & 2 & \multirow{2}{*}{4.34} & \multirow{2}{*}{0.88} & \multirow{2}{*}{1} & \multirow{2}{*}{$\begin{array}{l}\text { Very } \\
\text { agree }\end{array}$} \\
\hline & 53.9 & 32.8 & 8.6 & 3.1 & 1.6 & & & & \\
\hline \multirow{2}{*}{$\begin{array}{l}\text { 4. Taking care to know the } \\
\text { company's administrative } \\
\text { status before making } \\
\text { investment decision }\end{array}$} & 41 & 40 & 26 & 18 & 3 & \multirow[b]{2}{*}{3.76} & \multirow[b]{2}{*}{1.11} & \multirow[b]{2}{*}{4} & \multirow[b]{2}{*}{ Agree } \\
\hline & 32.0 & 31.3 & 20.3 & 14.1 & 2.3 & & & & \\
\hline \multirow{2}{*}{$\begin{array}{l}\text { 5. Taking care to know the } \\
\text { legal status of the company } \\
\text { before making investment } \\
\text { decision }\end{array}$} & 50 & 35 & 29 & 11 & 3 & \multirow[b]{2}{*}{3.92} & \multirow[b]{2}{*}{1.08} & \multirow[b]{2}{*}{3} & \multirow[b]{2}{*}{ Agree } \\
\hline & 39.1 & 27.3 & 22.7 & 8.6 & 2.3 & & & & \\
\hline The overall average of axis & & & & & & & 4.01 & 1.03 & Agree \\
\hline
\end{tabular}

The results of Table 13 indicate that there is a strong correlation between the reputation and history of the company and investment decision -making, with an overall arithmetic average of about (4.01) with a degree of (agree) and a standard deviation of about (1.03), meaning agreement of the sample members on the importance of the reputation and history of the company and investment decision making, the highest items had a very high degree of agreement in the two items of ( taking care to know the financial situation of the company before making investment decision) ( making sure to invest in companies with a good reputation ) with a degree of (very agree), an arithmetic average of 
about $(4.34$ ، 4.31$)$ respectively and a standard deviation of $(0.88$ ، 0.96$)$ while an item of (taking care to know the legal status of the company before making investment decision) had an arithmetic average of (3.92) and a standard deviation of (1.08) followed by an item of (taking care to know the company's administrative status before making investment decision) had an arithmetic average of (3.76) and a standard deviation of (1.11), and the lowest agreement degrees on the relationship between the reputation, history of the company and the decision of investment in an item of (no investment decision made before studying the company's situation in the past) with a degree of (agree ) and an arithmetic average of about (3.73) and a standard deviation of (1.10), indicating that the reputation and history of the company have a significant impact on the decision of investment.

The Third Axis: A Relationship Between Dividends and the Decision of Investment.

Table 14. Frequencies, percentages, arithmetic averages, standard deviations, and rankings of the items of the third axis

\begin{tabular}{|c|c|c|c|c|c|c|c|c|c|}
\hline \multirow[b]{2}{*}{ Item } & \multicolumn{5}{|c|}{ Degree of agreement } & \multirow[b]{2}{*}{ 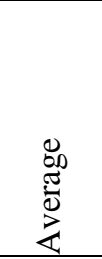 } & \multirow[b]{2}{*}{$\begin{array}{l}\text { Standard } \\
\text { deviation }\end{array}$} & \multirow[b]{2}{*}{ 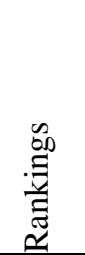 } & \multirow[b]{2}{*}{ 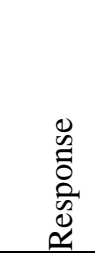 } \\
\hline & $\begin{array}{l}\text { Totally } \\
\text { agree }\end{array}$ & $\underset{\mathscr{L}}{\mathbb{E}}$ & $\begin{array}{l}\bar{\pi} \\
\vec{\Xi} \\
\overline{0}\end{array}$ & $\begin{array}{l}\text { Not } \\
\text { agree }\end{array}$ & $\begin{array}{l}\text { Not } \\
\text { very } \\
\text { agree }\end{array}$ & & & & \\
\hline \multicolumn{10}{|c|}{ Third axis : a relationship between dividends and the decision of investment } \\
\hline \multirow{2}{*}{$\begin{array}{l}\text { 1. My decision of } \\
\text { investment depends on the } \\
\text { company's dividends }\end{array}$} & 42 & 48 & 23 & 13 & 2 & \multirow[t]{2}{*}{3.89} & \multirow[t]{2}{*}{1.02} & \multirow[t]{2}{*}{1} & \multirow[t]{2}{*}{ Agree } \\
\hline & 32.7 & 37.5 & 18.0 & 10.2 & 1.6 & & & & \\
\hline \multirow{2}{*}{$\begin{array}{l}\text { 2. I do not invest in a } \\
\text { company with no } \\
\text { dividends in the past }\end{array}$} & 30 & 38 & 32 & 21 & 7 & \multirow[t]{2}{*}{3.49} & \multirow[t]{2}{*}{1.17} & \multirow[t]{2}{*}{4} & \multirow[t]{2}{*}{ Agree } \\
\hline & 23.4 & 29.7 & 25.0 & 16.4 & 5.5 & & & & \\
\hline \multirow{2}{*}{$\begin{array}{l}\text { 3. I do not invest in } \\
\text { companies with no } \\
\text { dividends at this present } \\
\text { time }\end{array}$} & 37 & 42 & 24 & 19 & 6 & \multirow{2}{*}{3.66} & \multirow{2}{*}{1.17} & \multirow{2}{*}{3} & \multirow{2}{*}{ Agree } \\
\hline & 28.9 & 32.8 & 18.8 & 14.8 & 4.7 & & & & \\
\hline \multirow{2}{*}{$\begin{array}{l}\text { 4. I do not invest in } \\
\text { companies that are not } \\
\text { expected to have a future } \\
\text { dividend }\end{array}$} & 44 & 38 & 25 & 14 & 7 & \multirow[t]{2}{*}{3.76} & \multirow[t]{2}{*}{1.19} & \multirow[t]{2}{*}{2} & \multirow[t]{2}{*}{ Agree } \\
\hline & 34.4 & 29.7 & 19.5 & 10.9 & 5.5 & & & & \\
\hline Overall average of axis & & & & & & & 3.70 & 1.13 & Agree \\
\hline
\end{tabular}

The results of Table 14 indicate that the relationship between dividends and the decision of investment has been agreed by the sample members with a degree of ( agree ), an arithmetic average of about (3.70) and a standard deviation of (1.13), which means that the sample agreement implies a correlation between dividends and making investment decision, particularly the highest item has agreement with an arithmetic average of about (3.89) and a standard deviation of (1.02) with a degree of (agree ) of an item of (my decision of investment depends on the company's dividends), followed by an item of (I don't invest in companies that are not expected to have a future dividend) with an arithmetic average of (3.76), and a standard deviation of (1.19), then an item of (I do not invest in companies with no dividends at this present time ) with an arithmetic average of (3.66) and standard deviation of (1.17), while the lowest items in the degree of agreement with an arithmetic average of about (3.49) and a standard deviation of (1.17), indicating that dividends also have an impact on the investment decision.

The Fourth Axis: A Relationship Between the Company's Founding Date and the Decision of Investment 
Table 15. Frequencies, percentages, arithmetic averages, standard deviations and rankings for the fourth axis items

\begin{tabular}{|c|c|c|c|c|c|c|c|c|c|}
\hline \multirow[b]{2}{*}{ Item } & \multicolumn{5}{|c|}{ Degree of agreement } & \multirow[b]{2}{*}{ 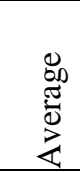 } & \multirow[b]{2}{*}{$\begin{array}{l}\text { Standard } \\
\text { deviation }\end{array}$} & \multirow[b]{2}{*}{ 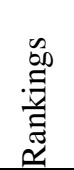 } & \multirow[b]{2}{*}{ 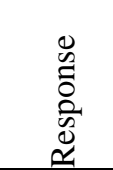 } \\
\hline & $\begin{array}{l}\text { Totally } \\
\text { agree }\end{array}$ & 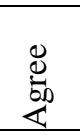 & $\begin{array}{l}\text { Neutra } \\
1\end{array}$ & $\begin{array}{l}\text { Not } \\
\text { agree }\end{array}$ & $\begin{array}{l}\text { Not } \\
\text { very } \\
\text { agree }\end{array}$ & & & & \\
\hline \multicolumn{10}{|c|}{ Fourth axis: a relationship between the company's founding date and the decision of investment } \\
\hline \multirow{2}{*}{$\begin{array}{l}\text { 1. I don't care about } \\
\text { investing in start-ups } \\
\text { companies }\end{array}$} & 15 & 26 & 36 & 37 & 14 & \multirow{2}{*}{2.93} & \multirow{2}{*}{1.18} & \multirow{2}{*}{4} & \multirow{2}{*}{ Neutral } \\
\hline & 11.7 & 20.3 & 28.2 & 28.9 & 10.9 & & & & \\
\hline \multirow{2}{*}{$\begin{array}{l}\text { 2. I make sure to invest } \\
\text { in companies that have a } \\
\text { long market time }\end{array}$} & 34 & 52 & 31 & 8 & 3 & \multirow{2}{*}{3.82} & \multirow{2}{*}{0.97} & \multirow{2}{*}{2} & \multirow{2}{*}{ Agree } \\
\hline & 26.6 & 40.6 & 24.2 & 6.3 & 2.3 & & & & \\
\hline \multirow{2}{*}{$\begin{array}{l}\text { 3. Long-term companies } \\
\text { in the market are able to } \\
\text { meet the challenges }\end{array}$} & 39 & 50 & 29 & 7 & 3 & \multirow[b]{2}{*}{3.89} & \multirow[b]{2}{*}{0.97} & \multirow[b]{2}{*}{1} & \multirow[b]{2}{*}{ Agree } \\
\hline & 30.5 & 39.1 & 22.6 & 5.5 & 2.3 & & & & \\
\hline \multirow{2}{*}{$\begin{array}{l}\text { 4. Long-term companies } \\
\text { in the market are safer } \\
\text { than start-ups companies }\end{array}$} & 32 & 47 & 39 & 6 & 4 & \multirow{2}{*}{3.75} & \multirow{2}{*}{0.98} & \multirow{2}{*}{3} & \multirow{2}{*}{ Agree } \\
\hline & 25 & 36.7 & 30.5 & 4.7 & 3.1 & & & & \\
\hline Overall average of axis & & & & & & & 3.60 & 1.02 & Agree \\
\hline
\end{tabular}

The results of the axis generally indicated agreement of the sample members to a relationship between the company's founding date and the decision of investment with an overall average of about (3.6) and a standard deviation of (1.02) which means agreement of the sample members on a relationship between the company's founding date and the decision of investment, in particular the highest items in terms of the degree of agreement of an item of (long-term companies in the market are able to meet the challenges) with an arithmetic average of about (3.89) and a standard deviation of (0.97), followed by an item of ( I make sure to invest in companies that have a long market time ) with an arithmetic average of (3.82) and a standard deviation of (0.97), then an item of (long-term companies in the market are safer than start-ups companies) with an arithmetic average of (3.75) and a standard deviation of (0.98), the lowest agreement degree with an arithmetic average of about (2.93), and a standard deviation of (1.18), with a neutral degree of an item of ( I don't care about investing in start-ups companies), which shows that the company's founding date has an effect of making investment decision as shown in Table 15.

The Fifth Axis: A Relationship Between the Company's Size and the Decision of Investment.

Table 16. Frequencies, percentages, arithmetic averages, standard deviations and rankings for the fifth axis items

\begin{tabular}{|c|c|c|c|c|c|c|c|c|c|}
\hline \multirow[b]{2}{*}{ Item } & \multicolumn{5}{|c|}{ Degree of agreement } & \multirow[b]{2}{*}{ 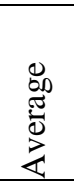 } & \multirow[b]{2}{*}{$\begin{array}{l}\text { Standard } \\
\text { deviation }\end{array}$} & \multirow[b]{2}{*}{ 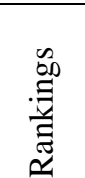 } & \multirow[b]{2}{*}{$\begin{array}{l}0 \\
\mathscr{0} \\
\tilde{0} \\
\stackrel{0}{0} \\
\tilde{0}\end{array}$} \\
\hline & $\begin{array}{l}\text { Totally } \\
\text { agree }\end{array}$ & $\underset{\square}{0}$ & 节 & $\begin{array}{l}\text { Not } \\
\text { agree }\end{array}$ & $\begin{array}{l}\text { Not } \\
\text { very } \\
\text { agree }\end{array}$ & & & & \\
\hline \multicolumn{10}{|c|}{ Fifth axis : a relationship between the company's size and the decision of investment } \\
\hline \multirow{2}{*}{$\begin{array}{l}\text { 1. I don't make investment } \\
\text { decision in small companies }\end{array}$} & 17 & 29 & 45 & 30 & 7 & \multirow{2}{*}{3.14} & \multirow{2}{*}{1.09} & \multirow{2}{*}{4} & \multirow{2}{*}{ Neutral } \\
\hline & 13.3 & 22.7 & 35.1 & 23.4 & 5.5 & & & & \\
\hline \multirow{2}{*}{$\begin{array}{l}\text { 2. Investment risks in small } \\
\text { firms are higher compared } \\
\text { to big companies }\end{array}$} & 31 & 54 & 28 & 13 & 2 & \multirow{2}{*}{3.77} & \multirow{2}{*}{0.98} & & \multirow{2}{*}{ Agree } \\
\hline & 24.2 & 42.2 & 21.8 & 10.2 & 1.6 & & & & \\
\hline \multirow{2}{*}{$\begin{array}{l}\text { 3. Small companies cannot } \\
\text { meet market challenges }\end{array}$} & 16 & 37 & 42 & 29 & 4 & \multirow{2}{*}{3.25} & \multirow{2}{*}{1.04} & \multirow{2}{*}{3} & \multirow{2}{*}{ Neutral } \\
\hline & 12.5 & 28.9 & 32.8 & 22.7 & 3.1 & & & & \\
\hline \multirow{2}{*}{$\begin{array}{l}\text { 4. Small companies cannot } \\
\text { seize a market share from } \\
\text { competitors }\end{array}$} & 16 & 47 & 42 & 20 & 3 & \multirow[b]{2}{*}{3.41} & \multirow{2}{*}{0.97} & \multirow[b]{2}{*}{2} & \multirow{2}{*}{ Neutral } \\
\hline & 12.5 & 36.8 & 32.8 & 15.6 & 2.3 & & & & \\
\hline Overall average of axis & & & & & & & 3.39 & 1.02 & Neutral \\
\hline
\end{tabular}


The results of the axis generally show a relationship between the company's size and the decision of investment from the viewpoint of the sample with a neutral degree, an average of about (3.39) and a standard deviation of (1.02), which means neutrality on a relationship between the company's size and the decision of investment, as a result, the highest items of agreement of an item of (investment risks in small firms are higher compared to big companies) has agreement degree with an arithmetic average of (3.77) and a standard deviation of (0.98), followed by an item of (small companies cannot seize a market share from competitors ) with an arithmetic average of (3.41) and a standard deviation of ( 0.97 ) with a neutral degree, then an item of (small companies cannot meet market challenges) with an arithmetic average of (3.25) and a standard deviation (1.04) with a neutral degree, while the lowest items of agreement have an arithmetic average of (3.14) and a standard deviation of (1.09) with a neutral degree in an item of ( I don't make investment decision in small companies), illustrating a relationship between the company's size and the decision of investment in small companies, as shown in table 16.

The Sixth Axis: A Relationship Between the Recommendations and Opinions of Analysts and the Decision of Investment.

Table 17. Frequencies, percentages, arithmetic averages, standard deviations and rankings for the sixth axis items

\begin{tabular}{|c|c|c|c|c|c|c|c|c|c|}
\hline \multirow[b]{2}{*}{ Item } & \multicolumn{5}{|c|}{ Degree of agreement } & \multirow[b]{2}{*}{ 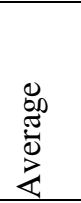 } & \multirow[b]{2}{*}{$\begin{array}{l}\text { Standard } \\
\text { deviation }\end{array}$} & \multirow[b]{2}{*}{ 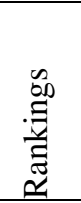 } & \multirow[b]{2}{*}{ 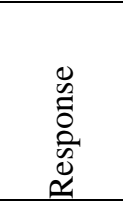 } \\
\hline & $\begin{array}{l}\text { Totally } \\
\text { agree }\end{array}$ & $\underset{\mathscr{E}}{\mathbb{E}}$ & $\begin{array}{c}\bar{E} \\
\stackrel{0}{0} \\
z\end{array}$ & $\begin{array}{l}\text { Not } \\
\text { agree }\end{array}$ & $\begin{array}{l}\text { Not } \\
\text { very } \\
\text { agree }\end{array}$ & & & & \\
\hline \multicolumn{10}{|c|}{$\begin{array}{l}\text { Sixth axis: a relationship between the recommendations and opinions of analysts and the decision of } \\
\text { investment. }\end{array}$} \\
\hline \multirow{2}{*}{ 1. I trust the opinions of analysts } & 15 & 33 & 51 & 18 & 11 & \multirow{2}{*}{3.17} & \multirow{2}{*}{1.08} & \multirow{2}{*}{2} & \multirow{2}{*}{ Neutra } \\
\hline & 11.7 & 25.8 & 39.8 & 14.1 & 8.6 & & & & \\
\hline \multirow{2}{*}{$\begin{array}{l}\text { 2. I make investment decision } \\
\text { based on the opinions of analysts }\end{array}$} & 13 & 35 & 40 & 25 & 15 & \multirow{2}{*}{3.04} & \multirow{2}{*}{1.16} & \multirow{2}{*}{4} & \multirow{2}{*}{ Neutral } \\
\hline & 10.2 & 27.3 & 31.3 & 19.5 & 11.7 & & & & \\
\hline \multirow{2}{*}{$\begin{array}{l}\text { 3. I make investment decision } \\
\text { based on the recommendations of } \\
\text { some persons }\end{array}$} & 16 & 38 & 37 & 25 & 12 & \multirow{2}{*}{3.16} & \multirow{2}{*}{1.16} & \multirow{2}{*}{3} & \multirow{2}{*}{ Neutral } \\
\hline & 12.5 & 29.7 & 28.9 & 19.5 & 9.4 & & & & \\
\hline \multirow{2}{*}{$\begin{array}{l}\text { 4. I make sure to get the opinion } \\
\text { of those who have a market } \\
\text { experience before making } \\
\text { investment decision }\end{array}$} & 29 & 65 & 23 & 8 & 3 & \multirow[b]{2}{*}{3.85} & \multirow[b]{2}{*}{0.92} & \multirow[b]{2}{*}{1} & \multirow[b]{2}{*}{ Agree } \\
\hline & 22.7 & 50.8 & 18 & 6.3 & 2.3 & & & & \\
\hline Overall average of axis & & & & & & & 3.30 & 1.08 & Neutral \\
\hline
\end{tabular}

The results of the axis generally indicated according to table (17) that a relationship between the recommendations, opinions of analysts and the decision of investment according to the sample's view with an average of (3.30), a standard deviation of about (1.08) and with a neutral degree that means that the sample members don't not agree on that relationship, and the highest items in terms of a degree of agreement for an item of (I make sure to get the opinion of those who have a market experience before making investment decision) with an arithmetic average of about (3.85) and a standard deviation of about (0.92), the rest of the items were neutral according to the sample's view with rankings as the following, an item of (I trust the opinions of analysts) with an arithmetic average of (3.17) and a standard deviation of (1.08), followed by an item of (I make investment decision based on the recommendations of some persons) with arithmetic average of (3.16), standard deviation of (1.16) and then an item of ( I make investment decision based on the opinions of analysts) with an arithmetic average of (3.04) and standard deviation of (1.16), so it can be said that the sample had a neutral degree of the opinion of experts and analysts when making investment decision.

The Seventh Axis: A Relationship Between the Nature of the Company's Activity and Investment Decision-Making. 
Table 18. Frequencies, percentages, arithmetic averages, standard deviations and rankings for the seventh axis items

\begin{tabular}{|c|c|c|c|c|c|c|c|c|c|}
\hline \multirow[b]{2}{*}{ Item } & \multicolumn{5}{|c|}{ Degree of agreement } & \multirow[b]{2}{*}{ 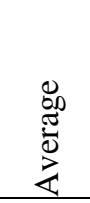 } & \multirow[b]{2}{*}{$\begin{array}{l}\text { Standard } \\
\text { deviation }\end{array}$} & \multirow[b]{2}{*}{ 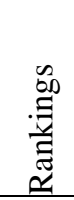 } & \multirow[b]{2}{*}{ 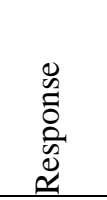 } \\
\hline & $\begin{array}{l}\text { Totally } \\
\text { agree }\end{array}$ & 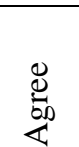 & 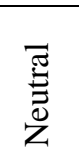 & $\begin{array}{l}\text { Not } \\
\text { agree }\end{array}$ & $\begin{array}{l}\text { Not } \\
\text { very } \\
\text { agree }\end{array}$ & & & & \\
\hline \multicolumn{10}{|c|}{$\begin{array}{l}\text { The seventh axis: a relationship between the nature of the company's activity and the decision of } \\
\text { investment }\end{array}$} \\
\hline \multirow{2}{*}{$\begin{array}{l}\text { 1. I make sure to invest in } \\
\text { specific companies or } \\
\text { sectors }\end{array}$} & 33 & 44 & 28 & 22 & 1 & \multirow{2}{*}{3.67} & \multirow{2}{*}{1.06} & \multirow{2}{*}{2} & \multirow{2}{*}{ Agree } \\
\hline & 25.8 & 34.3 & 21.9 & 17.2 & 0.8 & & & & \\
\hline \multirow{2}{*}{$\begin{array}{l}\text { 2. I avoid investing in } \\
\text { certain companies or sectors } \\
\text { even if they are good } \\
\text { companies }\end{array}$} & 25 & 39 & 34 & 26 & 4 & \multirow[b]{2}{*}{3.42} & \multirow[b]{2}{*}{1.11} & \multirow[b]{2}{*}{5} & \multirow[b]{2}{*}{ Neutral } \\
\hline & 19.5 & 30.5 & 26.6 & 20.3 & 3.1 & & & & \\
\hline \multirow{2}{*}{$\begin{array}{l}\text { 3. I make sure to invest in } \\
\text { industrial companies }\end{array}$} & 29 & 54 & 34 & 10 & 1 & \multirow{2}{*}{3.78} & \multirow{2}{*}{0.91} & \multirow{2}{*}{1} & \multirow{2}{*}{ Agree } \\
\hline & 22.7 & 42.2 & 26.6 & 7.7 & 0.8 & & & & \\
\hline \multirow{2}{*}{$\begin{array}{l}\text { 4. I make sure to invest in } \\
\text { service companies }\end{array}$} & 19 & 40 & 52 & 14 & 3 & \multirow{2}{*}{3.45} & \multirow{2}{*}{0.95} & \multirow{2}{*}{4} & \multirow{2}{*}{ Agree } \\
\hline & 14.8 & 31.3 & 40.6 & 10.9 & 2.4 & & & & \\
\hline \multirow{2}{*}{$\begin{array}{l}\text { 5. I make sure to invest in } \\
\text { financial companies }\end{array}$} & 22 & 53 & 41 & 9 & 3 & \multirow{2}{*}{3.64} & \multirow{2}{*}{0.93} & \multirow{2}{*}{3} & \\
\hline & 17.2 & 41.5 & 32 & 7 & 2.3 & & & & Agree \\
\hline \multirow{2}{*}{$\begin{array}{l}\text { 6. I make sure to invest in } \\
\text { luxurious companies }\end{array}$} & 14 & 34 & 64 & 10 & 6 & \multirow{2}{*}{3.31} & \multirow{2}{*}{0.93} & \multirow{2}{*}{6} & \multirow{2}{*}{ Neutral } \\
\hline & 10.9 & 26.6 & 50 & 7.8 & 4.7 & & & & \\
\hline Overall average of axis & & & & & & & 3.54 & 0.98 & Agree \\
\hline
\end{tabular}

The results of the overall average of the axis showed that there is a relationship between the nature of the company's activity and investment decision making according to the sample's view, with an arithmetic average of approximately (3.54) and a standard deviation of (0.98), which means the sample members' agreement on the importance of the nature of the company's activity in making investment decision, the highest degrees of agreement for an item of (I make sure to invest in industrial companies) with an arithmetic average of (3.78) and a standard deviation of about (0.91), followed by an item of ( I make sure to invest in specific companies or sectors ), with a arithmetic mean of (3.67) and a standard deviation of (1.06) with a degree of ( agree) ,then an item of (I make sure to invest in financial companies), with a arithmetic mean of (3. 64) and a standard deviation of (0.93) followed by an item of ( I make sure to invest in service companies ) with an arithmetic mean of ( 3.45$)$ and a standard deviation of (0.95) while the lowest degrees of agreement of a neutral category of an item of ( I avoid investing in certain companies or sectors even if they are good companies ), with an arithmetic mean of (3.42) and a standard deviation of (1.11) and an item of ( I make sure to invest in luxurious companies), with an arithmetic mean of (3.31), and a standard deviation of (0.93), thus it can be said that investors agreed on a relationship between the company's activity and they preferred industrial companies, specific, financial and service sectors, as shown in table (18).

\section{Results and Recommendations}

- The study concluded that investors in the Saudi stock market are interested in both: (ratios and financial analysis, the history and reputation of the company, dividends, company's founding date, company's size, recommendations and opinions of analysts, and nature of activity) before making investment decision at varying levels.

- The biggest investors' interests were the analysis and financial ratios of the company before making investment decision where the arithmetic average was 4.06 to be ranked first for investors.

- The reputation and history of the company ranked second as the results of the study indicated that investors are highly interested in the company's reputation and history before investing with an arithmetic average of 4.01 to be ranked second. 
- While an impact of dividends on the decision of investment ranked third with an arithmetic average of 3.70, this result confirms the conclusion of a study of (Al-Nemrouti \& Al-Owaisi, 2012) that dividends have an impact on investment decision.

- The fourth axis ranked fourth with an arithmetic average of 3.60 where the results of the study indicate that the company's founding date affects the decision of investment, while the nature of the company's activity ranked fifth with an arithmetic average of 3.54 , the results indicate that the nature of the company's activity has an impact on investment decision making of investors, and this confirms the findings of the study of (Al-Nemrouti \& Al-Owaisi, 2012) that investors prefer certain companies only.

- The company's size ranked sixth in investment decision, with an arithmetic average of this axis of 3.39.

- The impact of the recommendations and opinions of analysts on the investment decision of investors in the Saudi stock market ranked seventh and this result contradicts the findings of a study of (Hatef \& Al-Zubaidi, 2000) which is that non-financial information specially intermediaries' tips, bulletins and advertisements affect investors ' decision more likely compared to their benefit from accounting information. The difference may be caused by the variation of the target group and the study sample as well as the difference of period, this result is consistent with the findings of a study of (Al-Nemrouti \& Al-Owaisi, 2012) that the cadres of the brokering companies are not qualified to help investors make their decisions.

Finally, we can say arranged the factors affecting investor decisions when making the investment decision as follows: (ratios and financial analysis, the history and reputation of the company, dividends, company founding date, nature of activity, company size, recommendations and opinions of analysts). Investors' motives in trusting and relying on analysis and financial ratios, especially with the existence of various cases in which profit management and manipulation of financial statements were used, as happened in the American Enron Company. What are the reasons for poor investor confidence in the opinions of financial analysts? These are points that can be discussed in the future.

\section{References}

Abdullah, R. (2012). Efficiency of the stock market. Scientific Journal of Research and Business Studies, (4), 289-319.

Ahmed, H. B. (2016). The Effect of the behavioral biases on the decisions of investors in the Egyptian stock market. Journal of Business Administration, 153, 85-97.

Al-Buhaisi, E., \& Najm, A. (2009). The extent to which investors in the PSE recognize the importance of using accounting information to rationalize their investment decisions. Journal of the Islamic University for Human Research, 17(2), 713-739.

Al-Habashneh, F., Shahatit, M., Al-Badour, J., \& Amarin, Z. (2015). Factors Affecting the Market Price of the Amman Stock Exchange during the period 1984 - 2011. Studies-Administrative Sciences, 42(2), 461-472.

Al-Hossan, Z. (2002). The Determinants and Impediments of Investment in the Saudi Stock Market: A Field Study in the Qassim Region. Journal of Business Research, 24(1), 89-132.

Al-Naggar, J. H. (2017). Behavioral factors specific to decisions of investors and their impact on the performance of the investment portfolio, Analytical study of the Palestine Securities Exchange. Journal of the Arab American University for Research, 3(2), 109-153. https://doi.org/10.12816/0044528

Al-Nemrouti, K., \& Al-Owaisi, S. (2012). Analysis of the trends of investors in the Palestine Securities Exchange, a survey study on investors in the Gaza Strip. Journal of the Islamic University for Economic and Administrative Studies, 20(1), 1-36.

Al-Rajhi, Q., \& Al-Manasy, W. (2017). Studying the factors affecting the prices of shares of Saudi joint stock companies. Ramah Research \& Studies Magazine-Research \& Development Center, 23, 106-132.

Al-Saad, S. (2007). Environmental Review in Saudi Arabia: Current Practice and Future Outlook: A Field Study. Journal of Economics and Management, 21(2), 83-150. https://doi.org/10.4197/Eco.21-2.3

Assaf, S. M. (2012). Introduction to research in behavioral sciences. Kingdom of Saudi Arabia. Riyadh. Dar Al-Zahraa for Publishing and Distribution.

Ball, R., \& Brownt, P. (1968). An empirical evaluation of accounting income numbers. Journal of Accounting Research, 159-177. https://doi.org/10.2307/2490232 
Basheikh, A. (2006). A proposed model for determining the most important accounting information and its usefulness in rationalizing the decisions of small investors in the Saudi stock market. Egyptian Journal of Business Studies, 30(2), 357-370.

Capital Market Authority. (2018). General Certificate of Trading in Securities: Part II: Securities Operations (2nd ed.).

Eugene, F. (1970). Efficient Capital Markets: A Review of Theory and Empirical Work. The Journal of Finance, 25(2), 383-417. https://doi.org/10.1111/j.1540-6261.1970.tb00518.x

Financial Stability Report. (2017). Saudi Arabian Monetary Agency, (3).

Ghareeb, S. M. (2006). The role of the financial auditor in documenting environmental disclosure. The Journal of Saleh Abdullah Kamel Center for Islamic Economics, 10(29), 49-70.

Hatef, M., \& Al-Zubaidi, F. (2000). The extent of understanding and use of accounting information by investors in the Baghdad Stock Exchange: A field study. Jerash Journal for Research and Studies, 4(2), 41-58.

Jing, J. (2017). Cross-Sectional Variation of Market Efficiency. Review of Accounting and Finance, 16(1), 67-85. https://doi.org/10.1108/RAF-02-2016-0018

Lerner, J., Lemon, A., \& Du, S. (2017). Capital Market Authority and the collapse of the Saudi Stock Market in 2006. Bella Research Group. Retrieved from https://cma.org.sa/Market/Documents/CMA_Crash2006_ar.pdf

Mansi, A. (2009). Cognitive and emotional biases affecting individual investors: An applied study on the Saudi stock market. Journal of Finance and Trade, (479), 4-28.

Obidat, T., Abdelhak, K., \& Adas, A. (2007). Scientific research, its concept, tools and methods (10th ed.). Dar El Fikr Publishing \& Distribution.

Saudi Arabian Monetary Agency. (1997). Thirty-third Annual Report. Kingdom of Saudi Arabia. Riyadh: General Directorate of Economic Research and Statistics.

Saudi Arabian Monetary Agency. (2017). Fifty-third Annual Report. Kingdom of Saudi Arabia. Riyadh: General Directorate of Economic Research and Statistics.

Shahat, N., Siddiq, M., \& Mutawa, N. (2012). The Relationship between Behavioral Factors and Investor Decisions: An applied study on the Egyptian Stock Exchange. Egyptian Journal of Business Studies, 36(4), 185-224.

Shiraz, M. (2015). Statistical analysis of SPSS data. Scientific algorithm for publication and distribution (1st ed.).

Tadawul. (2005). Saudi Stock Market Journal, (12).

The Annual Report. (2017). Saudi Stock Exchange. Retrieved from http://cutt.us/ZeqmM

The Financial Entrepreneurship Program 2020. (2017). Capital Market Authority. Riyadh. Kingdom of Saudi Arabia. Retrieved from https://cma.org.sa/AboutCMA/Pages/FinancialLeadership2020.aspx

Yacoub, A. (2006). The Saudi Capital Market Crisis (BSE) An economic study. Saleh Kamel Center for Islamic Economics, 10(30), 217-267.

\section{Notes}

Note 1. Financial Market Regulation: https://cma.org.sa/RulesRegulations/CMALaw/Documents/CMALaw.pdf

Note 2. Capital Market Authority: https://cma.org.sa/AboutCMA/Pages/AboutCMA.aspx.

Note 3. Financial Market Authority: http://cutt.us/CnvO9.

Note 4. Financial Market Authority: http://cutt.us/o2Cmc.

Note 5. Financial Market Authority: http://cutt.us/CnvO9.

Note 6. Capital Market Authority: https://www.tadawul.com.sa/Resources/Reports/Yearly-HTML-ar.zip.

Note 7. NASDAQ is an acronym to: "National Association of Securities Dealers Automated Quotations system", A US financial market established in 1971. 